\title{
RESPIRATORY MUSCLE STRENGTH IN PATIENTS AFTER COVID-19
}

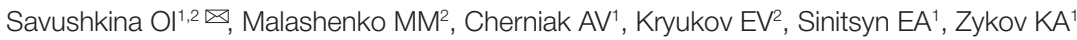

${ }_{1}^{1}$ Pulmonology Scientific Research Institute under Federal Medical Biological Agency, Moscow, Russia

${ }^{2}$ Main Military Clinical Hospital named after academician N. N., Ministry of Defense, Moscow, Russia

Respiratory muscles (RM) are a very important part of the respiratory system that enables pulmonary ventilation. This study aimed to assess the post-COVID-19 strength of RM by estimating maximum static inspiratory (MIP or PImax) and expiratory (MEP or PEmax) pressures and to identify the relationship between MIP and MEP and the parameters of lung function. We analyzed the data of 36 patients ( $72 \%$ male; median age 47 years) who underwent spirometry, and body plethysmography, diffusion test for carbon monoxide (DLCO) and measurement of MIP and MEF. The median time between the examinations and onset of COVID-19 was 142 days. The patients were divided into two subgroups. In subgroup 1, as registered with computed tomography, the median of the maximum lung tissue damage volume in the acute period was $27 \%$, in subgroup 2 it reached $76 \%$. The most common functional impairment was decreased DLCO, detected in 20 (55\%) patients. Decreased MIP and MEP were observed in 5 and 11 patients, respectively. The subgroups did not differ significantly in MIP and MEP values, but decreased MIP was registered in the second subgroup more often (18\%). There were identified no significant dependencies between MIP/MEP and the parameters of ventilation and pulmonary gas exchange. Thus, in patients after COVID-19, MIP and MEP were reduced in 14 and $31 \%$ of cases, respectively. It is reasonable to add RM tests to the COVID-19 patient examination plan in order to check them for dysfunction and carry out medical rehabilitation.

Keywords: respiratory muscle strength, spirometry, body plethysmography, diffusion test, post-COVID-19, new coronavirus infection

Funding: ordered by the state under the research topic "Impact of the new coronavirus infection SARS-CoV-2 on the functional parameters of respiratory system during the convalescence period" (code: "Post-COVID functional diagnostics").

Acknowlegements: we would like to thank Zaitov M. R., engineer of ZAO Meditsinskioye Sistemy, for technical support.

Author contribution: Savushkina OI — study design development, clinical material collection, analysis and interpretation of the results, article authoring; Malashenko MM - clinical material collection, interpretation of the results; Chernyak AV - study design development, clinical material collection, analysis and interpretation of the results, article editing; Kryukov EV — article concept development, editing; Sinitsyn EA — interpretation of the results, article editing; Zykov KA — article editing, approval of the final version of the manuscript.

Compliance with ethical standards: the study was approved by the Ethics Committee of the Pulmonology Scientific Research Institute of the FMBA of Russia (minutes № 01-21 of May 14, 2021). All study participants signed informed consent.

$\square$ Correspondence should be addressed: Olga I. Savushkina

Orekhovy bulvar, 28, Moscow, 115682; olga-savushkina@yandex.ru

Received: 19.07.2021 Accepted: 09.08.2021 Published online: 16.09.2021

DOI: $10.47183 /$ mes.2021.025

\section{ИССЛЕДОВАНИЕ СИЛЫ ДЫХАТЕЛЬНЫХ МЫШЦ У БОЛЬНЫХ, ПЕРЕНЕСШИХ COVID-19}

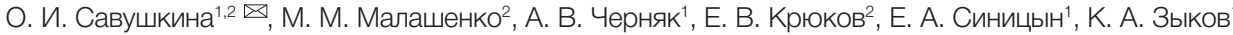

${ }^{1}$ Научно-исследовательский институт пульмонологии Федерального медико-биологического агентства, Москва, Россия

2 Главный военный клинический госпиталь имени Н. Н. Бурденко, Москва, Россия

\begin{abstract}
Дыхательные мышцы (ДМ) - важнейшее звено респираторной системы, обеспечивающее легочную вентиляцию. Целью исследования было оценить силу инспираторных (MIP) и экспираторных (MEP) ДМ после COVID-19 и выявить взаимосвязь показателей MIP и MEP с функциональными показателями системы дыхания. Проанализированы данные 36 пациентов (72\% мужчин; медиана возраста - 47 лет), которым проводили спирометрию и бодиплетизмограсию, определяли диффузионную способность легких (DLCO) и измеряли MIP/MEP. Медиана срока проведения исследований от начала COVID-19 составила 142 дня. Пациенты были разделены на две подгруппы. Медиана максимального объема поражения легочной ткани в острый период заболевания по КТ в подгруппе 1 составила 27\%, в подгруппе 2 - 76\%. Наиболее частым функциональным нарушением было снижение DLCO (выявлено у 20 (55\%) пациентов). Снижение MIP и MEP было отмечено у 5 и 11 пациентов соответственно. Статистически значимых различий по показателям MIP и MEP между подгруппами выявлено не было, однако частота снижения МIP во второй подгруппе была выше (18\%). Статистически значимых связей показателей МIP и МЕР с параметрами вентиляции и легочного газообмена выявлено не было. Таким образом, у пациентов, перенесших COVID-19, обнаружено снижение MIP и MEP в 14 и 31\% случаев соответственно. Исследование силы ДМ целесообразно включать в план обследования пациентов, перенесших COVID-19, для выявления их дисфункции и проведения медицинской реабилитации
\end{abstract}

Ключевые слова: сила дыхательных мышц, спирометрия, бодиплетизмография, диффузионный тест, пост-COVID-19, новая коронавирусная инфекция, SARS-CoV-2

Финансирование: в рамках выполнения государственного задания по теме: «Влияние новой коронавирусной инфекции SARS-CoV-2 на функциональные показатели системы дыхания в период реконвалесценции» (шифр: «Пост-COVID-функциональная диагностика»).

Благодарности: инженеру ЗАО «Медицинские системы» М. Р. Заитову за техническую поддержку.

Вклад авторов: О. И. Савушкина - разработка дизайна исследования, набор клинического материала, анализ и интерпретация результатов, написание текста; М. М. Малашенко - набор клинического материала, интерпретация результатов; А. В. Черняк - разработка дизайна исследования, набор клинического материала, анализ и интерпретация результатов, редактирование текста; Е. В. Крюков - концепция статьи, редактирование текста; Е. А. Синицын - интерпретация результатов, редактирование текста; К. А. Зыков - редактирование текста, утверждение итогового варианта текста рукописи

Соблюдение этических стандартов: исследование одобрено этическим комитетом НИИ пульмонологии ФМБА России (протокол № 01-21, от 14 мая 2021 г.). Все участники исследования подписали информированное согласие.

$\triangle$ Для корреспонденции: Ольга Игоревна Савушкина

Ореховый бульвар, д. 28, 115682, г. Москва; olga-savushkina@yandex.ru

Статья получена: 19.07.2021 Статья принята к печати: 09.08.2021 Опубликована онлайн: 16.09.2021

DOI: $10.47183 /$ mes.2021.025 
COVID-19 is a highly contagious infectious disease caused by the new coronavirus SARS-CoV-2. The virus attacks respiratory system as one of its main targets, and this attack is the main reason that brought such patients to the hospital. The research efforts focused on COVID-19 mainly aimed to investigate the pathogenesis of the disease and find ways to treat it at the acute phase in order to minimize mortality. However, with the accumulation of knowledge, it became clear that COVID-19 is a multisystem disease, the consequences of which are currently not well understood.

From the point of view of damage to the respiratory system, the main functional disorder in the post-COVID period is the reduced lung diffusion capacity; less common are restrictive ventilation disorders, and even less so are obstructive ventilation disorders [1-3]. The data obtained are taken into account when drawing up individual post-disease medical rehabilitation programs for COVID-19 patients. However, it is not just the respiratory system that needs medical rehabilitation after COVID-19 but also the cardiovascular system, as well as the peripheral skeletal muscles, which grow weak and fatigued in severe and extremely severe COVID-19 cases.

Respiratory muscles (RM), which are the most important component of the respiratory system that enabled pulmonary ventilation, also belong to the skeletal muscles. Pathological changes in the respiratory muscles that occur after communityacquired pneumonia (CAP) [4, 5] and thoracic interventions [6] have been studied well. A comparative analysis of the strength of RM in CAP cases of varying severity of endogenous intoxication showed that, causing local inflammation and damaging myofibrils [5], this intoxication is the dominant extrapulmonary mechanism triggering RM dysfunction. In addition, there is hyperventilation syndrome caused by arterial hypoxemia that also contributes to RM fatigue. Moreover, glucocorticosteroids may also be the reason of weakness $[7,8]$. However, there are just a few publications that investigate respiratory muscles strength after COVID-19 $[9,10]$.

The most common method for assessing RM strength is measurement of the maximum static mouth pressure when the person's airways are closed. This pressure may be expiratory (MEP) and inspiratory (MIP). Thus, this study aimed to assess the post-COVID-19 strength of RM and identify the relationship between MIP and MEP and other lung function parameters.

\section{METHODS}

The observational cross-sectional study included 36 patients (26 of them male, median age 47 years) admitted to hospitals with a diagnosed interstitial lung disease caused by the new coronavirus infection (J98.4). The inclusion criteria were: confirmed recovery from moderate or severe case of COVID-19, bilateral viral lung damage. In all patients the diagnosis was confirmed by polymerase chain reaction. The exclusion criterion was a recorded history of chronic lung disease. In the context of a single visit, all participants of this study underwent functional examinations of the respiratory system, including spirometry, body plethysmography, diffusion test and RM strength measurement. The system used for the examinations was the MasterScreen Body/Diff system (Viasys Healthcare / ErichJager, Vyaire Medical / ErichJager; Germany).

All procedures were carried out in accordance with national and international standards [11-14] and recommendations of the Russian Respiratory Society for conducting lung function tests during the COVID-19 pandemic [15]

The lung diffusing capacity was assessed for carbon monoxide measured by means of the single-breath test through the use of rapidly responding gas analyser (RGA).
Analyzed parameters:

1) spirometry (forced vital capacity (FVC), forced expiratory volume in $1 \mathrm{sec}\left(\mathrm{FEV}_{1}\right), \mathrm{FEV}_{1} / \mathrm{FVC}$, maximal mid-expiratory flow between $25 \%$ and $75 \%$ of the FVC expiration $\left(\mathrm{MMEF}_{25-75}\right)$ );

2) body plethysmography (slow vital capacity (VC), total lung capacity (TLC), residual volume (RV) and its ratio to TLC (RV/TLC), thoracic gas volume (TGV), inspiratory capacity (IC), total airways resistance $\left.\left(\operatorname{Raw}_{\text {tot }}\right)\right)$;

3) diffusion test (transfer factor CO (DLCO) adjusted for hemoglobin value and its ratio to alveolar volume (VA) DLCO/NA);

4) MIP and MEP.

The analyzed data were presented as a percentage of the predicted values $\left(\%_{\text {pred }}\right)$, which were calculated using the equations of the European Coal and Steel Community [16] for patient's gender, age and height. The predicted MIP and MEP values were calculated by the equations recommended the European Respiratory Society [17]. Values greater than $75 \%_{\text {pred }}$ were considered normal [18].

As registered with high-resolution chest computed tomography $(\mathrm{CT})$, there was post-inflammatory damage of varying severity in the lungs of the patients at the time of the study. The cohort was divided into two subgroups depending on the maximum area of lung damage caused by SARS-CoV-2 in the acute period of the disease. Patients whose lungs had $\leq 50 \%$ of tissue damaged were included in subgroup 1 , those with lung damage exceeding 50\% made up subgroup 2 .

Sixteen (44\%) patients had concomitant diseases: 7 patients - hypertension, 4 patients - hypertension and type 2 diabetes mellitus, one patient each - type 1 diabetes, varicose veins, myocarditis, psoriasis, iron deficiency anemia.

We employed STATISTICA 10.0 software (StatSoft Inc.; USA) for statistical analysis and Shapiro-Wilk test to assess the normality of distribution of the variables. Quantitative variables, the distribution of which differed from normal, were presented as medians $(\mathrm{Me})$ and interquartile range $\left(Q_{1}-Q_{3}\right)$, nominative variables - number of patients $(n)$. Comparison of nonparametric quantitative indicators of the two groups relied on the nonparametric Mann-Whitney $U$ test, that of qualitative variables - Fisher's exact test. Correlation analysis was performed using Spearman's rank correlation. The differences were considered significant at $p<0.05$.

\section{RESULTS}

The median duration of the lung function examination from the onset of COVID-19 was 142 (108-186) days.

Table 1 presents characteristics of all the patients participating in the study and their characteristics by subgroups.

There were no significant differences established between the subgroups by age, gender, height, body mass index.

The majority of patients in both subgroups were nonsmokers; only subgroup 1 had a small number of smokers.

The median value of the maximum lung damage area $\left(C T_{\text {max }}.\right)$ in the acute period of the disease was $27 \%$ in the 1 st subgroup and $76 \%$ in the $2^{\text {nd }}$ subgroup, which is a significant difference. The length of hospital stay for COVID-19 was significantly longer in subgroup 2.

Table 2 summarizes the functional examination data analysis overall and by subgroups.

For all the patients, the medians of all analyzed lung function parameters were within normal range, apart from the decreased DLCO in 20 (55\%) patients. In addition, 5 (14\%) patients had impairment of TLC, one patient had impairment of $\mathrm{VC}$ and $\mathrm{FEV}_{1} \mathrm{NC}\left(\mathrm{FEV}_{1} \mathrm{NC}<0.7\right), 5(14 \%)$ and $11(31 \%)$ 
Table 1. Patient characteristics

\begin{tabular}{|c|c|c|c|c|}
\hline Parameter & $\begin{array}{l}\text { Overall } \\
n=36\end{array}$ & $\begin{array}{c}\text { Subgroup } 1 \\
n=14\end{array}$ & $\begin{array}{c}\text { Subgroup } 2 \\
n=22\end{array}$ & $p^{*}$ \\
\hline Gender, men, $n(\%)$ & $26(72)$ & $8(57)$ & $18(82)$ & NS \\
\hline Age, years & $47(40-58)$ & $46(39-59)$ & $48(42-57)$ & NS \\
\hline Height, cm & $174(165-181)$ & $170(165-183)$ & 174 (165-179) & NS \\
\hline $\mathrm{BMI}, \mathrm{kg} / \mathrm{m}^{2}$ & $29(26-32)$ & $30(25-32)$ & $29(27-31)$ & NS \\
\hline $\begin{array}{l}\text { Tobacco smoking, } \\
\text { no/ex-smoker/smoker, \% }\end{array}$ & $69 / 28 / 3$ & $72 / 21 / 7$ & $68 / 32$ & - \\
\hline $\begin{array}{l}\text { Length of hospital stay } \\
\text { for COVID- } 19\end{array}$ & $18(13-25)$ & $14(8-16)$ & $23(15-27)$ & 0,01 \\
\hline
\end{tabular}

Note: the data are presented as quantity (n) or median (lower quartile — upper quartile). BMI — body mass index; * — subgroups 1 and 2 compared with MannWhitney test; NS - no significant differences found between subgroups 1 and 2.

patients had impairment of MIP and MEP, respectively. It should be noted that decreased TLC was found mainly in patients of subgroup 2, with only one such case registered in subgroup 1. Eight patients had the RV decreased, and 3 of them had the RV decreased isolated without impairment of TLC.

We found significant differences in TLC and DLCO values between the subgroups, these values being lower in subgroup 2 . The subgroups did not differ significantly in MIP and MEP values, but decreased MIP was registered in the second subgroup more often (18\%), while the frequency of decreased MEP was similar.

Correlation analysis did not reveal significant dependencies between MIP/MEP and the studied parameters of ventilation and pulmonary gas exchange.

\section{DISCUSSION}

Observation of COVID-19 convalescents indicates that after discharge from the hospital they do not fully recover functionally for a long time. Patients continue to experience shortness of breath, general weakness, increased fatigue and deteriorating quality of life. Besides, there are functional impairments of the respiratory system, cardiovascular system, as well as neuropathy and myopathy registered, which are primarily caused the extremely severe course of COVID-19 that required intensive care.

At the same time, even mild and moderate COVID-19 course brings the same symptoms with varying intensity of manifestation. The reduced RM strength is part of COVID-19induced neuropathy and myopathy, which indicates the need for medical rehabilitation interventions to remedy the symptoms.

The Experts Consensus concerning respiratory techniques which are recommended for inclusion in post-COVID-19 medical rehabilitation programs draws special attention to training of inspiratory muscles aimed at improving ventilationperfusion ratios and oxygenation [19]. However, this study shows that the reduced MEP registers twice as often as reduced MIP, that points out to justify breathing techniques in the context of training expiratory RM.

At the same time, physiotherapy methods such as electrical stimulation, chest massage with correction of muscle triggers and myofascial release, infrared laser therapy and magnetic therapy in the chest zones, help improve microcirculation and functional state of both inspiratory and expiratory RM.

Among the other findings of this study that draw attention is the lack of significant differences in MIP and MEP values between the subgroups, i.e., lack of confirmation the changes in these parameters depend on the lung damage severity during the acute period of the disease. The results obtained are consistent with those reported in the previously published studies [9, 10], which allows considering other factors, possibly biochemical, including those affecting the central mechanisms of respiration regulation and, accordingly, the functional state of RM after COVID-19.

The median duration of this study from the onset of COVID-19 was 142 days, and the most common functional impairment registered was decreased diffusion capacity (55\% of cases), mainly found in patients who had over $50 \%$ of their lungs damaged by the disease (subgroup 2), and restrictive ventilation disorders were diagnosed in $5(14 \%)$ patients, 4 of whom (18\%) were also in subgroup 2, while airways obstruction was only discovered in 1 patient. The meta-analysis that covered early post-COVID-19 period (1 to 3 months) showed that the prevalence of decreased diffusion capacity is $39 \%$ (Cl: 24-56\%; $p<0.01$; heterogeneity index $\left.\left(\mathrm{I}^{2}\right)-86 \%\right)$, whereas restrictive ventilation disorders is $15 \%(\mathrm{Cl}: 9-22 \%$; $\left.p=0.03 ; l^{2}=59 \%\right)$, airways obstruction $-7 \%(\mathrm{Cl}: 4-11 \%$; $\left.p=0.31 ; t^{2}=16 \%\right)[3]$.

The results of this study are consistent with the data of the meta-analysis, however, the present study addressed later post-COVID-19 recovery periods, which may indicate that, after this disease, the functions of the respiratory system recover slowly.

No statistically significant correlations were found between the maximum static mouth pressure and the lung function parameters, which once again confirms the importance of measuring RM strength, especially in patients who experience shortness of breath and rapid fatigue while having the traditional pulmonary functional tests return normal values.

The effect COVID-19 has on RM strength should be investigated further in order to uncover the relationship between MIP/MEP values and the quantitative assessment of muscle strength by the MRC Weakness scale, as well as the severity of dyspnea by the mMRC scale.

Particular attention to RM strength should be paid when COVID-19 takes extreme form and causes post-intensive care syndrome (PICS), including general muscle weakness, decreased muscle mass, reduced physical performance and muscle strength, and reduced strength of the inspiratory muscles that may result in diaphragm atrophy and dysfunction. Measurement of the MIP and MEP values over time in such patients will allow adjustment of the medical rehabilitation program and prediction of the outcomes of identified impairments. 
Table 2. Spirometry, body plethysmography, diffusion test, respiratory muscle strength test data

\begin{tabular}{|c|c|c|c|c|}
\hline Parameter & $\begin{array}{c}\text { Overall } \\
n=36\end{array}$ & $\begin{array}{c}\text { Subgroup } 1 \\
n=14\end{array}$ & $\begin{array}{c}\text { Subgroup } 2 \\
n=22\end{array}$ & $p$ \\
\hline VC, $\%_{\text {pred }}$ & $106(95-120)$ & $111(103-123)$ & $104(92-112)$ & NS \\
\hline VC $<80 \%_{\text {pred }}, n$ & 1 & 0 & 1 & NS \\
\hline FVC, $\%_{\text {pred }}$ & 109 (99-123) & $116(106-125)$ & $107(96-114)$ & NS \\
\hline $\mathrm{FEV}_{1}, \%_{\text {pred }}$ & $105(98-125)$ & $119(102-128)$ & $103(97-116)$ & NS \\
\hline $\mathrm{FEV}_{1}<80 \%_{\text {pred }}, n$ & 1 & 0 & 1 & NS \\
\hline $\mathrm{FEV}_{1}, \mathrm{NC}, \%$ & $82(78-84)$ & $82(78-84)$ & $83(78-86)$ & NS \\
\hline $\mathrm{FEV}_{1} / \mathrm{NC}<0.7, n$ & 1 & 0 & 1 & NS \\
\hline $\mathrm{FEV}_{1} / \mathrm{FVC}, \%$ & $83(80-85)$ & $82(80-84)$ & $83(80-86)$ & NS \\
\hline $\mathrm{MMEF}_{25-75}, \%_{\text {pred }}$ & $109(93-123)$ & $110(103-121)$ & $105(92-125)$ & NS \\
\hline TLC, $\%_{\text {pred }}$ & $100(90-109)$ & $108(98-114)$ & $97(85-105)$ & NS \\
\hline TLC $<80 \%_{\text {pred' }}, n$ & 5 & 1 & 4 & NS \\
\hline TGV, $\%_{\text {pred }}$ & 87 (75-101) & $93(75-105)$ & 85 (75-95) & NS \\
\hline IC, $\%_{\text {pred }}$ & $114(102-126)$ & $114(109-137)$ & $114(95-125)$ & NS \\
\hline $\mathrm{RV}, \%_{\text {pred }}$ & $88(81-97)$ & $89(81-97)$ & 85 (73-89) & 0.03 \\
\hline $\mathrm{RV}<80 \%_{\text {pred }}, n$ & 8 & 0 & 8 & 0.011 \\
\hline RV/TLC, $\%_{\text {pred }}$ & $83(78-89)$ & $108(98-119)$ & $82(79-86)$ & NS \\
\hline $\mathrm{Raw}_{\mathrm{tot}}, \mathrm{kPa} \cdot \mathrm{S} / \mathrm{L}$ & $0.22(0.17-0.29)$ & $0.23(0.19-0.30)$ & $0.2(0.17-0.29)$ & NS \\
\hline DLCO, $\%_{\text {pred }}$ & 77 (68-89) & 87 (76-95) & 72 (67-83) & 0.014 \\
\hline DLCO $<80 \%_{\text {pred }}, n$ & 20 & 5 & 15 & 0.058 \\
\hline DLCO/VA, $\%_{\text {pred }}$ & $90(82-98)$ & $96(86-103)$ & 87 (79-93) & NS \\
\hline MIP, $\%_{\text {pred }}$ & $108(89-135)$ & $114(91-137)$ & $102(85-129)$ & NS \\
\hline MIP decreased, $n$ & 5 & 1 & 4 & NS \\
\hline MEP, $\%_{\text {pred }}$ & 87 (72-105) & $86(74-108)$ & 87 (71-103) & NS \\
\hline MEP decreased, $n$ & 11 & 4 & 7 & NS \\
\hline
\end{tabular}

Note: data are presented as median (lower quartile — upper quartile); * - Mann-Whitney test applied to comparison of subgroups 1 and 2; NS — no significant differences found between subgroups 1 and 2 .

In addition, given that muscle strength directly depends on protein metabolism, it is advisable to analyze the relationship of total blood protein with MIP and MEP values, and in case of their decrease, consider nutritional support for the patients.

Thus, RM strength test is an important addition to the traditional pulmonary function tests in terms of information concerning the functional state of the RM that can be used in the context of prevention of pathological conditions and adequate clinical treatment.

\section{References}

1. Savushkina OI, Cherniak AV, Kryukov EV, Kulagina ITs, Samsonova MV, Kalmanova EN et al. Pulmonary function after COVID-19 in early convalescence phase. Medical alphabet. 2020; (25): 7-12. DOI: 10.33667/2078-5631-2020-25-7-12. Russian.

2. Zaitsev AA, Savushkina OI, Cherniak AV, Kulagina ITs, Kryukov EV. Clinical and functional characteristics of patients who recovered from the novel coronavirus infection (COVID-19). Practical pulmonology. 2020; 1: 78-81. Russian.

3. Torres-Castro R, Vasconcello-Castillo L, Alsina-Restoy X, SolisNavarro L, Burgos F, Puppo H, et al. Respiratory function in patients post-infection by COVID-19: a systematic review and meta-analysis. Pulmonology. 2021; 27 (4): 328-37. DOI: 10.1016/j.pulmoe.2020.10.013.

4. Dei AA, Kozhanov AG, Geltser BI. Results of respiratory muscle strength study in young persons with community-acquired

\section{CONCLUSIONS}

Patients that recovered from COVID-19 of varying severity exhibit decreased maximum static mouth pressure, specifically, expiratory pressure in $31 \%$ of cases and inspiratory pressure in $14 \%$ of cases. There were identified no significant dependencies between MIP/MEP values and the parameters of ventilation and pulmonary gas exchange. It is reasonable to add RM tests to the COVID-19 patient examination plan in order to detect their dysfunction and timely initiate a medical rehabilitation intervention. 
8. Segizbaeva MO, Aleksandrova NP. Assessment of the functional status of respiratory muscles: methodical aspects and interpretation of data. Human Physiology. 2019; 45 (2): 115-27. DOI: 10.1134/ S0131164619010120. Russian.

9. Huang $\mathrm{Y}$, Tan C, Wu J, Chen M, Wang Z, Luo L, et al. Impact of coronavirus disease 2019 on pulmonary function in early convalescence phase. Respir Res. 2020; 21 (1): 163. DOI: 10.1186/s12931-020-01429-6.

10. Guler SA, Ebner L, Beigelman C, Bridevaux P, Brutsche M, Clarenbach $\mathrm{C}$, et al. Pulmonary function and radiological features four months after COVID-19: first results from the national prospective observational Swiss COVID-19 lung study. Eur Respir J. 2021; 57 (4): 2003690. DOI: 10.1183/13993003.03690-2020.

11. Chuchalin AG, Aysanov ZR, Chikina SYu, Chernyak AV, Kalmanova EN. Federal guidelines of Russian Respiratory Society on spirometry. Pulmonology. 2014; (6): 11-23. Russian.

12. Graham BL, Steenbruggen I, Miller MR, Barjaktarevic IZ, Cooper BG. Hall GL, et al. Standardization of spirometry 2019 update an official American thoracic society and European respiratory society technical statement. Am J Respir Crit Care Med. 2019; 200 (8): 70-88. DOl: 10.1164/rccm.201908-1590ST.

13. Wanger J, Clausen JL, Coates A, Pedersen OF, Brusasco V, Burgos $F$, et al. Standardisation of the measurement of lung volumes. Eur Respir J. 2005; 26 (3): 511-22. DOI: 10.1183/09031936.05.00035005

14. Graham BL, Brusasco V, Burgos F, Cooper BG, Jensen R,
Kendricket A, et al. 2017 ERS/ATS standards for single-breath carbon monoxide uptake in the lung. Eur Respir J. 2017; 49: 1600016. DOI: 10.1183/13993003.00016-2016.

15. Aysanov ZR, Kalmanova EN, Kameneva MYu, Kirukhina LD, Lukina OF, Naumenko JK, at al. Guideline of the Russian Respiratory Society for functional diagnostics of the respiratory system during the COVID-19 pandemic. Ver. 1.1. from 19.05.2020. Available from: https://spulmo.ru/upload/rekomendacii_rro_fvd COVID_19_rev1_1_01062020.pdf. Russian.

16. Quanjer PH, Tammeling GJ, Cotes JE, Pedersen OF, Peslin R, Yernault JC. Lung volumes and forced ventilatory flows. Report Working Party Standardization of Lung Function Tests, European Community for Steel and Coal. Official Statement of the European Respiratory Society. Eur Respir J. 1993; 6 (Suppl.16): 5-40. PMID: 8499054.

17. Laveneziana P, Albuquerque A, Aliverti A, Babb T, Barreiro E, Dreset $\mathrm{M}$, et al. ERS statement on respiratory muscle testing at rest and during exercise. Eur Respir J. 2019; 53: 1801214. DOI: 10.1183/13993003.01214-2018.

18. Evans JA, Whitelaw W. The assessment of maximal respiratory mouth pressures in adults. Respir Care. 2009; 54 (10): 1348-59.

19. Bubnova MG, Shlyakhto EV, Aronov DM, Belevsky AS, Gerasimenko MYu, Glezer MG et al. Coronavirus disease 2019: features of comprehensive cardiac and pulmonary rehabilitation. Russian Journal of Cardiology. 2021; 26 (5): 4487. DOl: 10.15829/1560-4071-2021-4487.

\section{Литература}

1. Савушкина О. И., Черняк А. В., Крюков Е. В., Кулагина И. Ц., Самсонова М. В., Калманова Е. Н. и др. Функциональные нарушения системыдыханияв вериодраннего выздоровления после COVID-19. Медицинский алфавит. 2020; 25: 7-12. DOI: 10.33667/2078-5631-2020-25-7-12.

2. Зайцев А. А., Савушкина О. И., Черняк А. В., Кулагина И. Ц., Крюков Е. В. Клинико-функциональная характеристика пациентов, перенесших новую коронавирусную инфекцию COVID-19. Практическая пульмонология. 2020; 1: 78-81.

3. Torres-Castro R, Vasconcello-Castillo L, Alsina-Restoy X, SolisNavarro L, Burgos F, Puppo H, et al. Respiratory function in patients post-infection by COVID-19: a systematic review and meta-analysis. Pulmonology. 2021; 27 (4): 328-37. DOI: 10.1016/.jpulmoe.2020.10.013.

4. Дей А. А., Кожанов А. Г., Гельцер Б. И. Результать исследования силы дыхательных мышц у лиц молодого возраста с внебольничной пневмонией. Бюллетень физиологии и патологии дыхания. 2020; 77: 34-40. DOI: 10.36604/1998-5029-2020-77-34-40.

5. Гельцер Б. И., Дей А. А., Титоренко И. Н., Котельников В. Н. Сравнительный анализ силы дыхательных мышц при внебольничной пневмонии с различной тяжестью эндогенной интоксикации. Терапевтический архив. 2020; 92 (3): 19-24. DOI: $10.26442 / 00403660.2020 .03 .000372$.

6. Кожанов А. Г., Копаев В. А., Гельцер Б. И. Оценка силь дыхательных мышц в ранние сроки после торакальных вмешательств. Бюллетень физиологии и патологии дыхания. 2020; 75: 32-39. DOI: 10.36604/1998-5029-2020-75-32-39.

7. Авдеев С. Н. Оценка силы дыхательных мышц в клинической практике. Пульмонология и аллергология. 2008; 4: 12-17.

8. Сегизбаева М. О., Александрова Н. П. Оценка функционального состояния дыхательных мышц: методические аспекты и интерпретация данных. Физиология человека. 2019; 45 (2): 115-27. DOI: 10.1134/S0131164619010120.

9. Huang Y, Tan C, Wu J, Chen M, Wang Z, Luo L, et al. Impact of coronavirus disease 2019 on pulmonary function in early convalescence phase. Respir. Res. 2020; 21 (1): 163. DOI: 10.1186/s12931-020-01429-6.

10. Guler SA, Ebner L, Beigelman C, Bridevaux P, Brutsche M, Clarenbach $\mathrm{C}$, et al. Pulmonary function and radiological features four months after COVID-19: first results from the national prospective observational Swiss COVID-19 lung study. Eur Respir J. 2021; 57 (4): 2003690. DOI: 10.1183/13993003.03690-2020.

11. Чучалин А. Г., Айсанов З. Р., Чикина С. Ю., Черняк А. В. Калманова Е. Н. Федеральные клинические рекомендации Российского респираторного общества по использованию метода спирометрии. Пульмонология. 2014; 6: 11-23.

12. Graham BL, Steenbruggen I, Miller MR, Barjaktarevic IZ, Cooper BG, Hall GL, et al. Standardization of spirometry 2019 update an official American thoracic society and European respiratory society technical statement. Am J Respir Crit Care Med. 2019; 200 (8): 70-88. DOI: 10.1164/rccm.201908-1590ST.

13. Wanger J, Clausen JL, Coates A, Pedersen OF, Brusasco V, Burgos $F$, et al. Standardisation of the measurement of lung volumes. Eur Respir J. 2005; 26 (3): 511-22. DOI: 10.1183/09031936.05.00035005.

14. Graham BL, Brusasco V, Burgos F, Cooper BG, Jensen R, Kendricket A, et al. 2017 ERS/ATS standards for single-breath carbon monoxide uptake in the lung. Eur Respir J. 2017; 49: 1600016. DOI: 10.1183/13993003.00016-2016.

15. Айсанов З. Р., Калманова Е. Н., Каменева М. Ю., Кирюхина Л. Д., Лукина О. Ф., Науменко Ж. К. и др. Рекомендации Российского респираторного общества по проведению функциональных исследований системы дыхания в период пандемии COVID-19. Версия 1.1. от 19.05.2020. Доступно по ссылке: https://spulmo.ru/upload/rekomendacii_rro_fvd_ COVID_19_rev1_1_01062020.pdf.

16. Quanjer PH, Tammeling GJ, Cotes JE, Pedersen OF, Peslin R, Yernault JC. Lung volumes and forced ventilatory flows. Report Working Party Standardization of Lung Function Tests, European Community for Steel and Coal. Official Statement of the European Respiratory Society. Eur Respir J. 1993; 6 (Suppl.16): 5-40. PMID: 8499054.

17. Laveneziana P, Albuquerque A, Aliverti A, Babb T, Barreiro E, Dreset $\mathrm{M}$, et al. ERS statement on respiratory muscle testing at rest and during exercise. Eur Respir J. 2019; 53: 1801214. DOI: 10.1183/13993003.01214-2018.

18. Evans JA, Whitelaw W. The assessment of maximal respiratory mouth pressures in adults. Respir Care. 2009; 54 (10): 134859.

19. Бубнова М. Г., Шляхто Е. В., Аронов Д. М., Белевский А. С., Герасименко М. Ю., Глезер М. Г. и др. Новая коронавирусная инфекционная болезнь COVID-19: особенности комплексной кардиологической и респираторной реабилитации. Российский кардиологический журнал. 2021; 26 (5): 4487. DOI: 10.15829/1560-4071-2021-4487. 